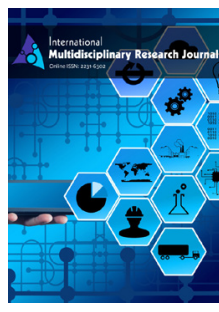

ISSN: $2231-6302$

\title{
Influencing factors to stay off-campus living by students
}

\author{
Shuvro Sen ${ }^{1 *}$, Neel Antara ${ }^{2}$ \\ 'Department of Management, University of Dhaka, Bangladesh, '2Department of English, Southeast University, Bangladesh
}

Received: April 22, 2018 Accepted: June 01, 2018 Published: June 14, 2018

*Corresponding Author: Shuvro Sen

Email: Senshuvro.du@gmail. com

\begin{abstract}
The advanced education framework has quickly changed on the planet. In these days, individuals are continually endeavoring to accomplish the higher education. Hence, the demand for the educational institution, leaving spaces, infrastructural development is expanding step by step. This investigation has been embraced to perceive the components that impact an understudy in considering the choice to remain in off-grounds living in the season of advanced education. This investigation has been done through an organized survey \& finished by factor analysis strategy. The discoveries demonstrated that maximum understudies pick off-grounds living to guarantee their solace, accommodation, and wellbeing in a peaceful perusing condition. Off-grounds living understudies need to endure enormous challenges regarding cost, transportation, connecting with social activities, and so forth. Government and University experts can take some preventive ways like building lobbies, expanding transportation facilities, diminishing the cost of nourishment, and so forth to minimize the problems of off-grounds livings students.
\end{abstract}

KEYWORDS: Off-campus living, university students, students' housing, comfort, convenient, safety, factor analysis. JEL Classification Number: C83, H52, I23.

\section{INTRODUCTION}

Lodging is an indispensable component in everyone's life. It creates the impact on understudies in their scholarly area. The Students' lodging is comprised of two kinds of housing which are living off-grounds occupant and living on-grounds tenant. On-grounds living arrangement implies living in the territory of land that contains the primary structures of a college or school [1]. Living off-grounds is an understudies' lodging situated outside of the grounds. Off-grounds living understudies are required to be in a loft, apartment suite, patio, semi-segregated, or a solitary abiding. Understudies lodging is as a basic segment to them to extend their scholarly capacities. Additionally, it teams up with understudies to accomplish the more extensive targets. It additionally depicts an essential part in the scholarly help. Solace, comfort, wellbeing, quiet living condition, understudies' cooperation in social exercises, lodging physical encompassing, and so on are imperative components of a tutees' prosperity. In any case, these variables might miss when an understudy begins living in off-grounds. Off-grounds living understudies have constrained access to the facilities of the institution however they are allowed to enter in the libraries and different offices gave by the institution. As off-grounds living understudies need to settle outside of the grounds without their family, they stand up to issues in a few divisions like house rent, security, nourishment, transportation, doing goods, and so on. Moreover, non-residential students encounter various problems, for example, facing neighbourhood disputes, severed landlords and landladies relationships, noise problem, environmental pollution, shortage of resting places, frequent shortages of water, disputes over payment of monthly electricity bills etc. [2]. Understudies' homes assume a critical part on understudies. Lodging condition can impact understudies' sentiment solace, network, and affirmation [3]. It has been recognized that grounds living understudies have higher Grade Point Averages (GPA). They can assume more praise hours. In addition, they can manufacture a decent association with their senior understudies of their specializations [4]. There is a connection between the living condition and the scholastic execution of understudies. Higher Educational Institutions understudies' have an alternate sort of living background because of the assorted variety of lodging choices and situations accessible [5]. So there is a distinction in the scholarly execution of understudies who are remaining in ongrounds and off-grounds lodging. They found that On-grounds understudies' execution is superior to off-grounds understudies in their scholarly part. Students' lodging isn't just incorporate lodging yet additionally incorporate natural and social exercises identified with scholastic viewpoints [6].

\section{LITERATURE REVIEW}

One of the conspicuous inquiries for universities understudies is the place they will live after university confirmation. They

Copyright: $\odot 2018$ The authors. This article is open access and licensed under the terms of the Creative Commons Attribution License (http://creativecommons.org/licenses/by/4.0/) which permits unrestricted, use, distribution and reproduction in any medium, or format for any purpose, even commercially provided the work is properly cited. Attribution - You must give appropriate credit, provide a link to the license, and indicate if changes were made. 
can live in on-grounds or off-grounds. The choice has differed from individual to individual. This choice relies upon numerous variables like the family choice, security, comfort, cost, transportation facilities, and so on.

It has been also found that students' living condition plays an important role in the academic support mission related to student affairs [7]. Student success and perseverance can be impacted by living environment factors. University living condition influences students' life and likewise their conduct [8]. Additionally, grounds living encourages an understudy to include in social exercises which aren't workable for the understudies who live off-grounds [9]. Moreover, many researchers examined the contrasts between on-grounds living and off-grounds living. They found that off-grounds living comprises of a fundamental room with other shared offices like lavatories, toilets, kitchens, and so on. Then again, lobby life incorporates rooms, lavatories, and toilets with other lodging offices, for example, a play area, shops in the area [10]. Likewise, some researchers completed an examination on the difficulties of off-grounds understudies. They discovered some vital components which make an understudy satisfied or disappointed. It has been found that an understudy becomes satisfied to stay in off-campus living when they can stay near the campus, can collaborate with other residents' friend, can hang out with friends easily \& can stay near to many facilities. On the other hand, they become dissatisfied when they have to stay in limited spaces, having limited financial support, limited room furniture, limited public transport \& parking spaces. Moreover, noisy places, bad smell, immoral behavior of neighbor, fear of theft \& so many unpleasant things can be reasons for dissatisfaction among students who live in the off-campus living [11]. There may be huge distinguish in the area of the living arrangement like the level of security; nearness to university; accessibility of pantries; web access; security; PC labs; blended home; recreation center; room furniture and the number of inhabitants in a unit etc. And these fundamental factors influence understudies' decision of inhabitance in exclusive living arrangements [12]. There are some factors of student residence satisfaction which are: cleanliness, safety, room size, security, gym facility, location, internet access, study areas, laundry room, water supply, etc. [13]. A recent study conducted in Nigeria found that students were dissatisfied with the residences features. They always face some problems such as distance to shopping areas, health center, and recreational facilities etc. [14]. Students prefer off-campus living because on-campus living has lack of privacy, noisy environment, shared bed space etc. Hence, understudies incline toward remaining off-grounds homes that are reasonable, private, close to grounds and having additional offices [15].

To evade these issues, understudies pick off-grounds living. Additionally, there are a few advantages like.

- Living off grounds can be a more reasonable alternative.

- One can learn prominently significant life lessons by paying bills and going shopping for food.

- Living off grounds exhibits an understudy his/her own space and a different mentality.

- It is considerably more casual to have companions. Along these lines, one can remain with companions at the house which may not be conceivable in lobby life.

- In living off-grounds, there is an enormous chance to think about. It's not possible for anyone to irritate you.

Along these lines, with numerous professionals and cons of living off-grounds, it a conspicuous examination point why understudies favor off-grounds living.

\section{MATERIALS AND METHODS}

\section{Sources of Data Collection, Sampling Method and Sample Size of the Study}

The data, which is used to decorate the study, has been collected from both the primary and secondary sources. Most of the information has been collected from the primary sources through a questionnaire and an informal interaction. The vital part of the study has been done by surveying respondents. The secondary data have been collected from the previous journals, books \& research.

Convenience sampling method has been applied for selecting respondents as it allows the researcher to gather basic data regarding the study without any complications. Only 100 students were selected as respondents.

\section{Research Instrument}

A self-administered questionnaire was prepared based on literature review \& objectives of the study. The questionnaire occupied three parts. To determine the influencing factors in taking the decision to stay in off-campus living, factor analysis method was applied. Basically, to measure the unit of variables, all the items were supported with 5 point Likert scales. The range of the scale is One to Five, where Strongly Disagreed $=$ One, Disagree = Two, Neutral $=$ Three, Agree $=$ Four $\&$ Strongly Agreed $=$ Five .

\section{ANALYSIS AND DISCUSSION}

\section{Demographic Profile of the Respondents}

In this study, there were 100 respondents. Among of them $75 \%$ were males \& $25 \%$ were females. Most of the respondents were 20-22 years. Conferred upon the demographic information, which is mentioned in (Table 1), it was found that only $10 \%$ respondents were born in Barishal, 30\% were in Chittagong, $45 \%$ were in Dhaka, $8 \%$ were in Rajshahi \& another $7 \%$ were in Khulna. Almost $75 \%$ respondents were in Bachelor program \& other 25\% were in Master's program.

This study tried finding out the major influencing factors of a student to consider the decision of staying off-campus. The following graph will help to furnish some basic information.

Figure 1 shows the reasons of why students aren't keen to stay in the hall. About 36\% respondents faced scarcity of seat in 
their assigned hall. Another, 36\% respondents didn't linger in the hall for their convenience. $16 \%$ respondents said they had faced family pressure not to stay in the hall.

Figure 2 shows that about $64 \%$ respondents didn't willing to change their accommodation from off-campus to on-campus while another, $36 \%$ participants in this study were willing to switch their house.

Now the arising question is what might be the reasons behind to change the accommodation. Figure 3 shows that most of the respondents (about 56\%) wished for changing their accommodation to minimize their monthly cost. Other $22 \%$ respondents desired to do it to stay safe, $13 \%$ respondents

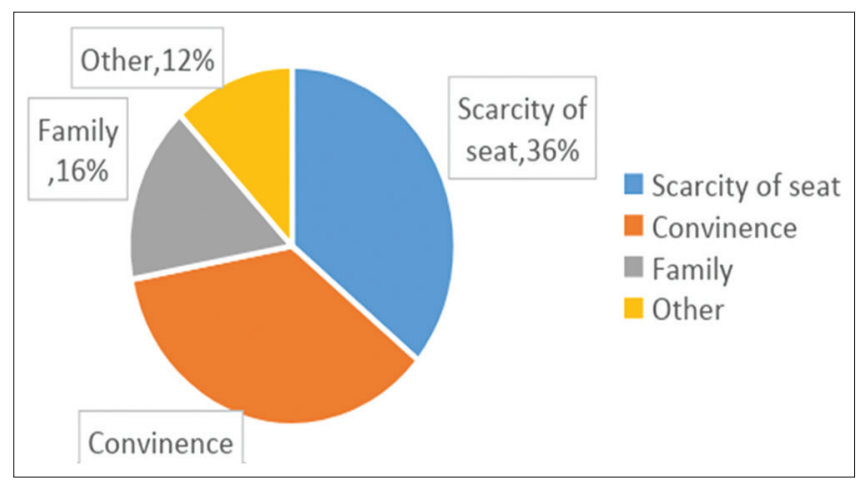

Figure 1: Why you don't stay in your hall

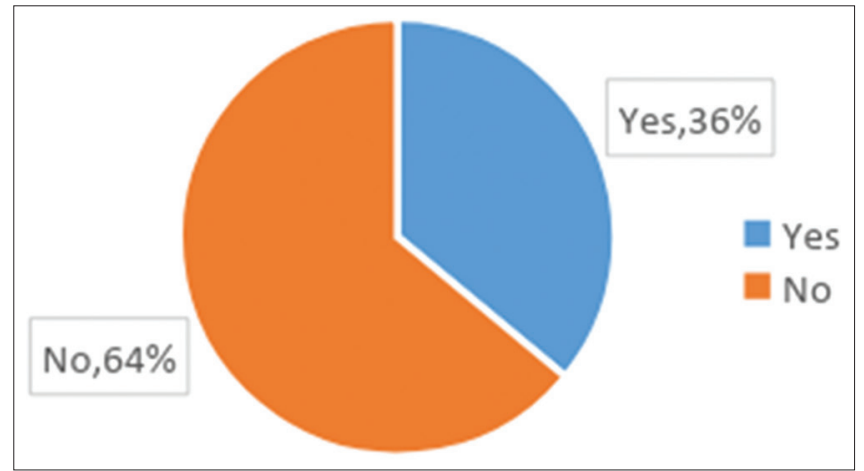

Figure 2: Will you change your accommodation, if an option has been given to you

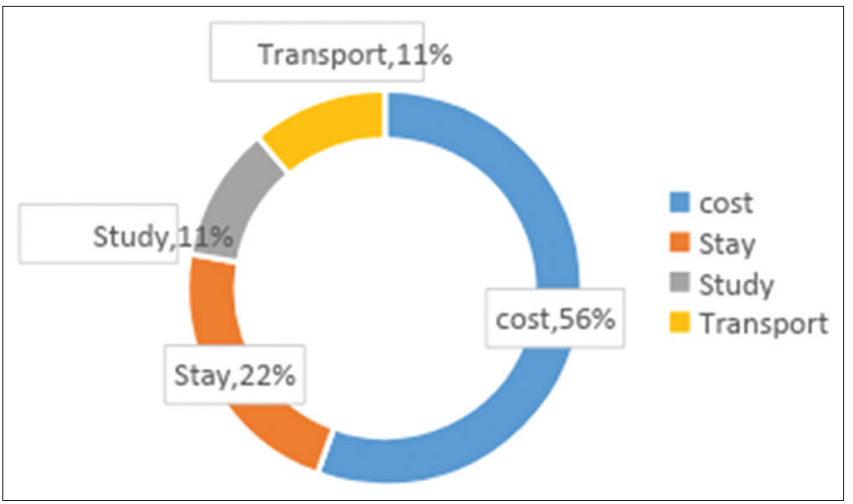

Figure 3: The reasons behind to change accommodation wanted to study properly \& $11 \%$ respondents wanted to minimize the transportation problems.

Figure 4 shows that $64 \%$ respondents had to spend 5000 - above 10000 BDT to stay outside of the campus. Only $36 \%$ respondents had to spend below 5000 BDT in every month.

Figure 5 shows that off-campus living students had to spend $44 \%$ of their monthly cost in the food sector. About $24 \%$ of their monthly cost went to bear utility bill \& other costs. Moreover, they had to spend $12 \%$ for their house \& $20 \%$ for their cloth.

Table 1: Demographic information of the respondent

\begin{tabular}{lllcc}
\hline Serial No. & Variable & Categories & $\begin{array}{c}\text { Frequency } \\
(n=100)\end{array}$ & Percentage \\
\hline 1 & Gender & Male & 75 & 75 \\
& \multirow{4}{*}{ Age of respondents } & Female & 25 & 25 \\
& Below 20 & 12 & 12 \\
& $20-21$ & 25 & 25 \\
& $21-22$ & 23 & 23 \\
& $22-23$ & 10 & 10 \\
& & $23-24$ & 18 & 18 \\
& & Above 24 & 12 & 12 \\
& Place of birth of & Barisal & 10 & 10 \\
& respondents & Chittagong & 30 & 30 \\
& & Dhaka & 45 & 45 \\
& & Khulna & 7 & 7 \\
& & Mymensingh & 0 & 0 \\
& & Rajshahi & 8 & 8 \\
& & Rangpur & 0 & 0 \\
& & Sylhet & 0 & 0 \\
& & Bachelor & 75 & 75 \\
& & Masters & 25 & 25
\end{tabular}

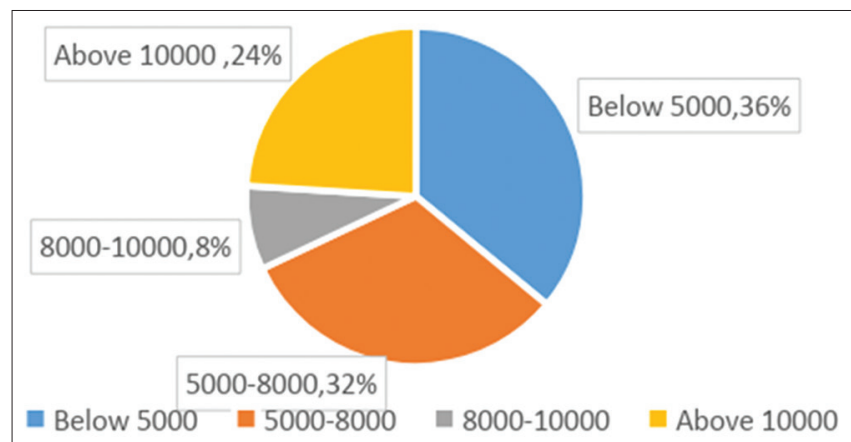

Figure 4: Monthly cost of the respondents

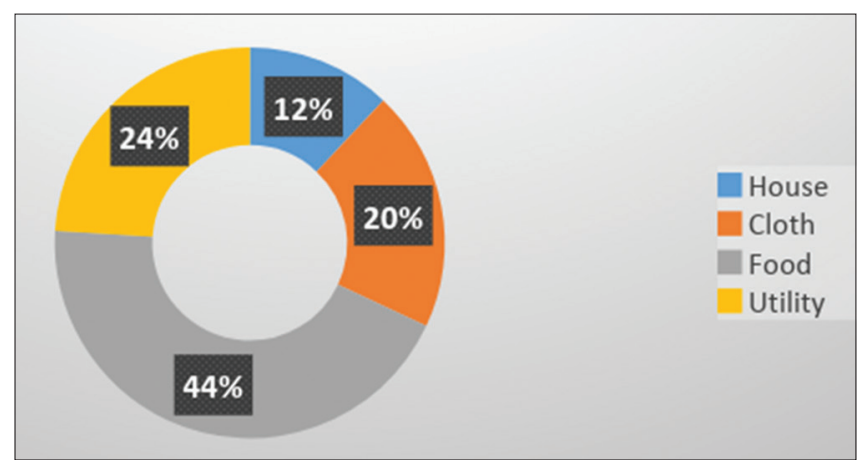

Figure 5: Most spendable sector

Int Multidiscip Res J • 2018 
Table 2: Eigenvalue of the factors

\begin{tabular}{llllllllllll}
\hline Factor & Factor 1 & Factor 2 & Factor 3 & Factor 4 & Factor 5 & Factor 6 & Factor 7 & Factor 8 & Factor 9 & Factor 10 & Factor 11 \\
\hline Eigenvalue & 3.39344 & 1.46408 & 1.09027 & 0.77443 & 0.45355 & 0.29453 & 0.19828 & -0.07086 & -0.10334 & -0.15308 & -0.24176 \\
\hline
\end{tabular}

Table 3: Factor loading estimates

\begin{tabular}{llccc}
\hline Serial No. & Variables & Factor- 1 & Factor-2 & Factor-3 \\
\hline 1 & Comfort & 0.6569 & 0.0220 & -0.0856 \\
2 & Safety & 0.8551 & -0.3499 & -0.0778 \\
3 & Housing facility near the campus & 0.4790 & 0.5095 & -0.2261 \\
4 & Having single room & 0.6947 & -0.0469 & -0.3169 \\
5 & Food arrangement & 0.7252 & -0.2541 & 0.0212 \\
6 & Participated in social activities & 0.5198 & 0.5458 & -0.1538 \\
7 & Other facilities & 0.3557 & 0.6022 & 0.3343 \\
8 & Reading environment & 0.6947 & -0.0469 & -0.3169 \\
\hline
\end{tabular}

Table 4: Measuring communality

\begin{tabular}{llcc}
\hline Serial No. Variables & Uniqueness & $\begin{array}{c}\text { Communality } \\
\left(\begin{array}{c}\left.\text { (loading }_{v}\right)^{2} \\
\text { or (1- uniqueness) } \%\end{array}\right.\end{array}$ \\
\hline 1 & Cost afford & 0.6483 & $0.3517=35 \%$ \\
2 & Comfort & 0.2691 & $0.7309=73 \%$ \\
3 & Safety & 0.0713 & $0.9287=92 \%$ \\
4 & Housing facility near the & 0.2491 & $0.7509=75 \%$ \\
& campus & & \\
5 & Reading environment & 0.2319 & $0.7681=76 \%$ \\
6 & Food facilities & 0.1986 & $0.8014=80 \%$ \\
7 & Social activities & 0.2163 & $0.7837=78 \%$ \\
8 & Other facilities (Internet, & 0.3708 & $0.6292=63 \%$ \\
9 & Printing Facility, etc.) & & \\
10 & Furnished room & 0.3527 & $0.6473=65 \%$ \\
11 & Theft fear & 0.3173 & $0.6827=68 \%$ \\
\hline
\end{tabular}

Table 5: Explained variance

\begin{tabular}{llcc}
\hline Serial No. & Factors & Proportion & Explained variance \\
\hline 1 & Factor 1 & 0.4780 & 0.8376 or $84 \%$ \\
2 & Factor 2 & 0.2062 & \\
3 & Factor 3 & 0.1536 & \\
\hline
\end{tabular}

\section{Result of Factor Analysis}

In this study, for analyzing the collected data factor analysis method has been applied.

The factor analysis indicates the strongly associated elements for considering the off-campus living decision by students. The result of correlation of factor analysis is displayed in (Figure 6). In this analysis, there were 11 variables found with their eigenvalue, which is mentioned in (Table 2). From the Table 2, the first 3 factors (factor- 1 , factor- $2 \&$ factor-3) were identified by using eigenvalue greater than one rule. These three factors with the factor loading of 0.5 and above have been selected. Because in 1998, Hair et al. suggested that variables with factor loadings $0.5 \&$ above are very significant to determine the minimum loading necessary to comprise an item. From the result of the factor analysis, factor loading has also been found, which is shown in (Figure 7). It has been seen that 8 variables are strongly correlated with some specific factors. Inherently,

\begin{tabular}{|c|c|c|c|c|c|}
\hline \multicolumn{3}{|c|}{$\begin{array}{l}\text { Fact or anal ysi s/cortel ation } \\
\text { Met hod: princi pal fact ors } \\
\text { Rot ati on: (unt ot at e } 6 \text { ) }\end{array}$} & \multicolumn{2}{|c|}{$\begin{array}{l}\text { Nunter of obs: } \\
\text { Ret ai ned factors : } \\
\text { Nunter of params : }\end{array}$} & $\begin{array}{r}24 \\
7 \\
55\end{array}$ \\
\hline Fact of & Ei genval ue & Difference & Proportion & Oumul at ive & \\
\hline Fact or 1 & 3. 39344 & 1. 92936 & 0.4780 & 0.4780 & \\
\hline Fact of 2 & 1. 46408 & 0.37380 & 0.2062 & 0.6842 & \\
\hline Fact or 3 & 1. 09027 & 0. 31584 & 0.1536 & 0.8378 & \\
\hline Fact or 4 & 0.77443 & 0.32087 & 0.1091 & 0.9469 & \\
\hline Fact or 5 & 0.45355 & 0.15902 & 0.0639 & 1. 0107 & \\
\hline Fact or 6 & 0.29453 & 0.09626 & 0.0415 & 1.0522 & \\
\hline Fact or 7 & 0.19828 & 0.26914 & 0.0279 & 1.0802 & \\
\hline Fact or 8 & -0.07086 & 0.03248 & -0.0100 & 1.0702 & \\
\hline Fact or 9 & .0 .10334 & 0.04974 & .0 .0146 & 1.0556 & \\
\hline Fact of 10 & $\cdot 0.15308$ & 0.08869 & -0.0216 & 1.0341 & \\
\hline Fact of 11 & -0.24176 & & -0.0341 & 1.0000 & \\
\hline
\end{tabular}

Figure 6: Factor Analysis

\begin{tabular}{|c|c|c|c|c|c|c|c|c|}
\hline Variable & Fact or 1 & Factor 2 & Fact or 3 & Factor 4 & Fact or 5 & Fact or 6 & Factor 7 & Uni queness \\
\hline$i c$ canaf ford 4 & 0.0883 & 0.0676 & $\cdot 0.4309$ & -0.0317 & 0.2608 & 0.2865 & 0.0508 & 0.6483 \\
\hline If feel comfore & 0.6569 & 0.0220 & $\cdot 0.0856$ & 0.4654 & 0.2628 & 0.0428 & 0.0636 & 0.2691 \\
\hline myhouseissve & 0.8551 & $\cdot 0.3499$ & $\cdot 0.0778$ & 0.0108 & 0.2208 & $\cdot 0.1418$ & 0.0014 & 0.0713 \\
\hline uni ver sityм & 0.4790 & 0.5095 & $\cdot 0.2261$ & 0.3168 & $\cdot 0.2415$ & 0.1557 & $\cdot 0.1670$ & 0.2491 \\
\hline youhaveanexy & 0.6947 & $\cdot 0.0469$ & $\cdot 0.3169$ & 0.1470 & $\cdot 0.2962$ & $\cdot 0.2624$ & 0.0681 & 0.2319 \\
\hline foodar rangere & 0.7252 & $\cdot 0.2541$ & 0.0212 & $\cdot 0.3841$ & 0.1210 & $\cdot 0.0334$ & $\cdot 0.2174$ & 0.1986 \\
\hline I partici pay & 0.5193 & 0.5458 & $\cdot 0.1538$ & -0.4285 & 0.0170 & 0.0371 & 0.0819 & 0.2163 \\
\hline i haveal I ki M & 0.3557 & 0.6022 & 0.3343 & -0.1501 & 0.0075 & -0.0410 & -0.0625 & 0.3708 \\
\hline myroom sfund & 0.6109 & $\cdot 0.1182$ & 0.3349 & $=0.1132$ & $\cdot 0.1623$ & 0.1515 & 0.2930 & 0.3527 \\
\hline idont havea of & 0.3405 & 0.0237 & 0.7006 & 0.2474 & 0.0689 & 0.0631 & -0.0733 & 0.3173 \\
\hline icangooutsm & -0.3148 & 0.5790 & 0.0261 & 0.0839 & 0.2750 & $\cdot 0.2576$ & 0.1002 & 0.4060 \\
\hline
\end{tabular}

Figure 7: Factor loading

it indicates what extent those variables load on the factors, which is shown in (Table 3).

In Table 4, it has been shown how much a single variable has in common with all factors. It has also been shown the percentage of a variable's variation that is explained by the factors. A relatively high commonality indicates that a variable has much in common with the other variables taken as a group. A relatively low communality means the variable does not sustain an established relationship with the other variables. From Table 4, it has been observed that "Study Environment" is the highest commonality variable \& "Affordable Cost" is the lowest commonality variable.

It has been found that the factor 1 , factor 2 and factor 3 have been explained $84 \%$ of the total variance. The calculation is shown in (Table 5).

\section{CONCLUSION}

The examination is planned to recognize the affecting variables to remain off-grounds living by understudies. The present investigation has uncovered some intriguing perspectives from off-grounds living understudies. These perspectives are probably going to be useful for college expert. There is an enormous 
shortage of seat in the University's lobby. All understudy can't remain in the lobby, in spite of their ability. They need to expend a monstrous measure of cash to remain in an abundant room and their sustenance division. A large portion of the understudies would prefer not to settle in grounds lobby in light of the fact that there are a few confinements like the shortage of seat, low nourishment quality, low web office, ragging, and so on.

University specialist can construct a few more lobbies to limit the shortage of the seat with expanding transportation offices so that off-grounds living understudies can come and go to grounds. Lobby expert can expand sustenance quality. The Government can set up a rental and wellbeing rule to end up a center individual between understudy's family and landowner. Likewise, University specialist can support off-grounds living understudies to play out their program, exercises and group benefit. What's more, lobby expert can give free web surfing (wired and $\mathrm{Wi}-\mathrm{Fi}$ ), self-benefit clothing and humble parlors to take care of the issues looked by the off-grounds living students.

\section{ACKNOWLEDGEMENTS}

We would like to show our gratitude to the respondents for providing necessary information. We are also immensely grateful to Mr. Hafij Ali, Biology Lab Manager, Independent University, Bangladesh (IUB) for his comment in a previous version of the manuscript although any errors in this paper's findings, interpretation $\&$ conclusion are our own and for this reason the reputations of the esteemed person should not be faded.

\section{REFERENCES}

1. TheFreeDictionary.com. Available from: https://www. thefreedictionary.com/on-campus [Accessed 7 Apr. 2018].
2. Addai, Isaac. Problems of Non-Residential Students in Tertiary Educational Institutions in Ghana: A Micro-Level Statistical Evidence. Journal of Emerging Trends in Educational Research and Policy Studies (JETERAPS). 2013; 4(4):582-588. Available from https:// www.questia.com/library/journal/1P3-3160848831/problems-of-nonresidential-students-in-tertiary-educational.

3. Khozaei F, Amole D, Hassan A.S, Khozaei Z. Female Graduate Students' Perception of the Relationships between the Residence Hall and the Home. Asian Social Science. 2010; 6(10):68-76.

4. Agron J. Innovations in residence-life programming. American School \& University. 1997; 69:81-87.

5. Kolawole O.A, Boluwatife A.R. Assessment of the factors influencing students' choice of residence in Nigerian tertiary institutions. Sainshumanika. 2016; 8(2):39-47.

6. Oluwaseyi B. The Effects of Students' Housing on Academic Performance at the University of Ibadan in Nigerian. International Journal of Scientific \& Engineering Research. 2015; 06(03):1118-1132.

7. Thomas E. Ware Jr., Michael T. Miller. Current Research Trends in Residential Life. ERIC - Education Resources Information Center. 1997-00-00; 1-9. Available from www.eric.ed.gov/ERICWebPortal/ recordDetail?accno $=\mathrm{ED} 416744$.

8. Baird L. Theoretical Approaches to the College Environment. Journal of College Student Personnel. 1978; 19(4):309-313.

9. Feldman K. A. Studying the Impact of College Students. Sociology of Education. 1969; 42(3):207-230.

10. Nurul 'Ulyani Mohd Najib, Nor' Aini Yusof, Nazirah Zainul Abidin. Student residential satisfaction in research universities. Journal of Facilities Management. 2011; 9(3):200-212.

11. Muhammad Hilmy Muslim, Hafazah Abdul Karim, Ishak Che Abdullah. Challenges of Off-Campus Living Environment for Non-Resident Students' Well-Being in UiTM Shah Alam. Procedia - Social and Behavioral Sciences. 2012; 50:875-883.

12. Tidimalo Kobue, Ayodeji Oke, Clinton Aigbavboa. Understanding the Determinants of Students' Choice of Occupancy for Creative Construction. Procedia Engineering. 2017; 196:423-428. Avaiable from http://dx.doi.org/10.1016/j.proeng.2017.07.219.

13. Khozaei F, Amole D, Hassan A.S, Khozaei Z. Female Graduate Students Perception of the Relationships between the Residence Hall and the Home. Asian Social Science. 2010; 6(10):68-76.

14. Adeleye O. An Assessment of Housing Satisfaction among Pre-Degree Students of Obafemi Awolowo University, Ile-lfe, Nigeria. Civil and Environmental Research. 2014; 6(8):169-178.

15. Devlin A.S, Gender-role and Housing Preferences. Journal of Environmental Psychology. 1994; 14(3):225-235. 